\title{
O DIREITO CRIADOR DE INIMIGOS COMO CONSEQUÊNCIA DO COMODISMO JURÍDICO
}

THE ENEMY CREATING LAW AS A CONSEQUENCE OF LEGAL COMODISM

\section{Gabriel Coimbra Rodrigues Abboud ${ }^{1}$} André Luís Jardini Barbosa ${ }^{2}$

ISSUE DOI: $10.21207 / 1983.4225 .537$

\footnotetext{
${ }^{1}$ Aluno do quinto ano de direito da Faculdade de Direito de Franca. Atualmente, exerce estágio no Ministério Público Estadual (PJ-Guará/SP) e participa da monitoria da Faculdade de Direito de Franca, ministrando reforço da disciplina de Direito Penal I.

${ }^{2}$ Graduado em Direito pela Faculdade de Direito de Franca (2000), Especialista em Direito Processual Penal pela Escola Paulista da Magistratura e Mestre pela Universidade Estadual Paulista - UNESP (2008). Doutorando em Direito pela Faculdade Autônoma de Direito/FADISP. Delegado de Polícia do Estado de São Paulo. É Professor das cadeiras de Investigação Policial e Inquérito Policial da Academia de Polícia Doutor Coriolano Nogueira Cobra.
} 


\section{RESUMO}

O objetivo principal do presente trabalho é demonstrar como, pelo passar dos tempos, a acomodação do meio acadêmico jurídico somado à seletividade da lei em suas vertentes é capaz de trazer malefícios para a toda a sociedade. Os efeitos desta catástrofe vão ser uma ramificação tanto da mercantilização do ensino jurídico, como da desmazela dos juristas perante a ideia de que estamos sob um arcabouço legal justo e, acima disso, pleno. Palavras-chave: Sistema punitivo. Inimigo. Lei. Mercantilização do ensino. Senso comum.

\section{ABSTRACT}

The main objective of the present work is to demonstrate how, over time, the accommodation of the legal academic environment plus the selectivity of the law in its aspects is capable of bringing harm to the whole of society. The effects of this catastrophe will be a rationalization of both the commercialization of legal education and the mismatch of jurists with the idea that we are under a fair legal framework and, above all, full.

Keywords: Punitive system. Enemy. Law. Merchanization of teaching. Common sense.

\section{ENTRE CAMINHOS E UTOPIAS}

A norma enquanto orientação cogente - e desta forma imposta de um território deve adequar-se às necessidades deste, mas jamais ao seu simples senso comum - jamais tornar-se simbolismo -. No entanto, vigente no Brasil um código punitivo da primeira metade do século $\mathrm{XX}$, não se pode esperar amoldamento preciso às conjunturas atuais de maneira alguma.

Desta forma, o que se sucede é que a punição se tornou de forma sorrateira, cada vez mais seletiva, e a aplicação efetiva da lei cada vez mais 
restrita na medida em que a concentração de poder e renda foi se consolidando:

(...) não é necessário que todos os fatos criminosos sejam castigados, porque não haveria juízes em número suficiente para fazê-lo e tampouco carrascos para executar suas ordens. Deste modo, para dez crimes, há apenas uma condenação e normalmente os condenados são ardilosos. Aqueles que têm amigos ou dinheiro habitualmente escapam das mãos dos homens. $^{3}$

Usou-se da punição como meio de segregação, perverte-se toda a ordem jurídica para que os privilégios tomem espaço no Estado de Direito. Deste modo, não se pode mais afastar o plano jurídico em seu todo da classe das superestruturas.

Clareada esta perspectiva, o direito como máquina estrutural legitimadora de cerceamento de espaços cumpre perfeitamente seu papel, principalmente o direito penal, que surge como a demonstração mais violenta da vontade estatal. Percebe-se desta forma pois, coisificadas as relações pessoais e consumada a exploração do ser humano como força de trabalho, o idealismo que todo o estudo jurídico propõe cai por terra, mas ao mesmo tempo se mantém no plano físico e fático.

O pensamento ora clássico acaba sendo facilmente remontado ao cenário coevo da sociedade, não só brasileira, mas de parte predominante de todo o globo. Assim, delineando a ideia que o senso comum será coagido a engolir, a sequência sem fim se perfaz de forma a determinar que, a depender de sua classe, haverá mais ou menos chances de um dia, eventualmente, ser considerado como suspeito, um investigado. Em seguimento, a lei dirá que é um inimigo, a imprensa convencerá de que é capaz e possível de seguir os padrões de vida e comportamento burgueses. Caso desobedeça aos comandos que os ordenadores darão, a tropa estará pronta para garantir que as garantias sejam desrespeitadas.

A ideia que se busca incutir à mente daqueles que se encontram à deriva é a de criar a ilusão de que a vida da plebe tem o mesmo valor que

${ }^{3}$ BODIN, Jean. De la demonomamie des sorciers. De l'inquisition des sorciers. Livro IV, Capítulo 5, "De la peine qui méritent les sorciers", 215-217, Paris, chez Jacques du Pues, Libraire Iuré, 1587. p. 215-217. 
o sangue azul, que o voto do trabalhador tem o mesmo peso do feito pelo megaempresário. Contudo, no fim, a base da pirâmide é vista com olhos a julgarem serem vidas indignas de serem vividas, que cuja morte significaria uma salvação, para a sociedade e para o estado especialmente, a libertação de uma carga, cuja manutenção não produz o mínimo proveito ${ }^{4}$.

O que se busca propagar é que os cidadãos estão fadados a caírem em contos criados, em fazer deles meros fantoches nas mãos do poderio. Cria-se na mente do homem comum que ele é capaz de crescer, aceder e transcender a todos, no entanto, trata-se de ideia que é extremamente útil para aumentar sua produção ao passo que se procede explorado.

A maneira mais cômoda de calar inimigos, mais simples do que calá-los de fato, é trancafiá-los em presídios, é mais simples pois é a morte espiritual do criminoso, isola-o até que sua mente definhe, é mais simplória pelo fato de se usar a via institucional, portanto, não existirão obstáculos para a segregação. O isolamento do hostis também é dotado de plenitude legal.

Convencidas as massas de que existe sim um inimigo, o próximo passo é tornar padronizados os conceitos humanos. Na prática, o que acontece é que a cultura da periferia vai ser transformada em "subcultura", pelo fato de restringir à classe baixa que, mesmo em maioria numérica, sente-se menor, haja vista sua falta de representatividade. Nas escolas não serão ensinados sobre, as influências não seguirão da sua forma, os meios de comunicação não mostrarão, serão taxados como rebaixados. Tudo sob a regulamentação e padrões legais. Desta maneira será feito com a cultura, num momento apropriado com a conduta e, por fim, criminalizado serão os instintos mais humanos que essa universalização de uma cultura centralizada pode causar.

Embora exista a alimentação diária da necessidade de um Estado extremamente punitivista, a realidade demonstra o real contrário. Muito se esbraveja pelo país de que reina a impunidade, porém, tal discurso até poderia ser usado, se o fosse da maneira correta. No entanto, a realidade mostra outra face.

O Brasil, como exemplo, tendo a $4^{\mathrm{a}}$ maior população carcerária do mundo, somente por este já não poderia mais usar de tal speech. Além disso, exibe, entre os países comparados, a quinta maior taxa de presos sem

${ }^{4}$ BINDING, Karl; HOCHE, Alfred. La licencia para la aniquilación de la vida sin valor de vida. Tradução de B. Sergiós. Buenos Aires: Ediar, 2009. 
condenação. Do total de pessoas privadas de liberdade no Brasil, aproximadamente quatro entre dez (41\%), estavam presas sem ainda terem sido julgadas $^{5}$. Do total, a população carcerária brasileira cresce cerca de $7 \%$ ao ano. O último relatório do Departamento Penitenciário Nacional do Ministério da Justiça (Depen) estimou que a população prisional brasileira ultrapassou 600 mil presos. A curva de crescimento, acentuada pela nova lei de drogas promulgada em 2006, é assustadora - segundo o próprio Depen em 2006 tínhamos 47 mil presos por crimes de drogas (14\% do total). Em 2013 passaram a 138 mil (1 em cada 4 presos) -. De 2002 a 2013, segundo o IBGE, a população brasileira cresceu $15 \%$, ao passo que a população carcerária mais do que dobrou (um aumento de $140 \%$ ) no mesmo período ${ }^{6}$.

Quanto mais punitivismo, mais criminalidade, e a razão disto é óbvia, o encarceramento e a punição, não podem ser usados como meio, tampouco fim de reduzir o número de crimes, pois não é parte da solução do problema, muito pelo contrário, é parte determinante de sua criação, consolidação e piora. Seria atacar os sintomas da doença, e não sua verdadeira causa, é como privilegiar o curativo à vacina.

O que se percebe é que o que fora dito é sabido dos próceres, no entanto, para que a causa fosse de fato medicada, erradicada, o efeito primeiro seria a destruição de todo o conceito de inimigo que a sociedade contemporânea propõe, para que, segundo Guilherme Moreira Pires, em projeções extremamente futuras, os controles sejam abolidos, os castigos e autoridades, dissolvidos, estancando suas produções de falsas verdades ${ }^{7}$. Assim, o extermínio restaria deslegitimado.

Diante de tamanho cenário de valorização da vida, resta ao estado policial, bebendo de magistério de Foucault, recorrer ao "racismo de Estado":

No contínuo biológico da espécie humana, o aparecimento das raças, a hierarquia das raças, a qualificação de certas raças como boas e de outras, ao contrário, como inferiores, tudo isso vai ser uma

\footnotetext{
${ }^{5}$ Levantamento Nacional De Informações Penitenciárias Infopen - 2014. p. 13.

${ }^{6}$ Informativo Rede Justiça Criminal - Quais são os números da justiça criminal no Brasil? p. 4.

${ }^{7}$ PIRES, Guilherme Moreira e CORDEIRO, Patrícia. Abolicionismos e cultura libertária: inflexões e reflexões sobre estado, democracia, linguagem, delito, ideologia e poder. Editora Empório do Direito. 2017.
} 
maneira de fragmentar esse campo do biológico de que o poder se incumbiu; uma maneira de defasar, no interior da população, uns grupos em relação a outros ${ }^{8}$.

A partir deste momento é autorizado a criar-se desconfiança sobre a verdadeira função do sistema jurídico, penal e prisional. O que a lei legitima, a cadeia cala. De fora das celas não se podem ouvir os gritos, de dentro dos poderes tampouco; a propaganda fala mais alto do que os clamores daqueles que chamam e o som dos tiros são o martelo final nos berros das periferias.

Com o sentido de cegar as massas em relação a essa carnificina que o Brasil tolera, é necessário que o estado eterno de guerra seja escondido ou que as instituições funcionem de maneira plena.

Para assegurar isso, cria-se o que Zaffaroni e Guillamondegui chamam de "direito penal de emergência". Este ideal caracteriza-se por três aspectos principais predominantes: $i$ ) Reclamo da opinião pública; ii) Adoção de sanção como regras diferentes das contempladas pelo modelo vigente; iii) Adoção e um direito penal meramente simbólico.

Verdadeiramente, no âmbito político como prática desta urgência penal, essa ânsia pela punição, seus agentes buscam dar impressão tranquilizadora de um legislador atento e indeciso, porém, na verdade são os primeiros a assumir as funções de carrasco daqueles que na verdade necessitam dos olhares.

Observada toda essa sistemática, o que se percebe é que a inimização é um dos frutos do sistema penal atual, não somente dele, mas de forma imediata. Ou seja, a somatória deste direito penal simbólico e o punitivismo descompassado que se encontra o Brasil tem como consequência mais do que óbvia um direito penal do inimigo pleno e a respirar ar puro à plenos alvéolos. Tal é último de um direito penal de puro risco que se desenvolveu e continua na direção errada ${ }^{9}$.

${ }^{8}$ FOUCAULT, Michel. Em defesa da sociedade. São Paulo. Martins Fontes, 2005. p. 304.

${ }^{9}$ PRITTWITZ, Cornelius. O direito penal entre o direito penal do risco e o direito penal do inimigo: tendências atuais entre direito penal e política criminal. Revista Brasileira de Ciências Criminais, n. 47. São Paulo: Revista dos Tribunais, mar.- abr.2004, p. 31-45, esp. p.32. 
No fim, toda a população acaba por se transformar em eternos temerosos fantasmas da família Joad ${ }^{10}$, que endividados pelos bancos e financistas, são seduzidos por promessas e acabam por serem colocados para dormir embaixo de uma ponte, ao longo da estrada, vendendo sua mão de obra por dignidade, e junto deles, um imenso número de pessoas.

Na verdade, toda a questão de um certo darwinismo social vem à tona em todo discurso punitivo, principalmente quando parte dos operados pelo direito. Em ilustração, é interessante perceber que contemporaneamente existe uma crítica de peso ao estereótipo escrito por Cesare Lombroso $^{11}$ em sua obra, que basicamente caracteriza criminosos por seus aspectos físicos. No entanto, ainda existem mentes "refinadíssimas" que, em seu foro mais íntimo ou no seu falar mais público, julgam de maneira vil e inescrupulosa os infratores de códigos - ou melhor, os intitulados criminosos -, sem sequer olhar para eles da maneira como verdadeiramente são, e o fazem de maneira puramente "lombrosiana" forma quase cirúrgica, veze ou outra de forma mais precisa do que o próprio cientista italiano.

Estes legitimadores de medidas e atitudes excepcionais são instrumentos da fábrica de criar inimigos que se engrandece a cada segundo, são soldados de uma sociedade autótrofa. Estão em desconforme com o Estado de direito, pois é um princípio que não comporta exceções, considerando sua função orientadora instrumentalizada do Direito Penal. Em verdade, vislumbrando quadros utópicos, o penalismo não deverá reconhecer inimigos e não terá espaço para exclusão de indivíduos em função de sua própria existência ${ }^{12}$. Honestamente, somente deste ponto em diante pode passar-se a discutir em plenitude de garantias.

Assim sendo, a plenitude de garantias processuais jamais será suficiente para declarar a igualdade como consolidada. A realidade social grita e pouco é ouvida, muitos são processados, sentenciados e trancados

\footnotetext{
${ }^{10}$ STEINBECK, John. As vinhas da ira. Tradução de Herbert Caro e Ernesto Vinhaes. $10^{a}$ edição. Editora Record, 2012.

${ }^{11}$ LOMBROSO, Cesare. O homem delinquente. Tradução de Sebastião José Roque. Ícone, 2007.

${ }^{12}$ AMBOS, Kai. Derecho penal del inimigo. Tradução de Carlos Gómez-Jara Diéz y Miguel Lamadrid. Colombia: Universidad Externado de Colombia, 2007. p. 53.
} 
sem nem sequer entenderem o motivo do que lhes acontece. Agora, transformam-se em clones de Joseph $\mathrm{K}^{13}$, pois, guiados pelo desconhecido legal e métodos de acusação, tornam-se reféns do judiciário sem sequer saberem qual crime cometeram e se o cometeram de fato. Interessante notar a semelhança do cidadão médio e o protagonista de Franz Kafka perante a justiça, considerando que desconhecem os trâmites legais, desconhecem as capitulações, ignoram qualquer procedimento, porém, são os primeiros a receberem as garras da justiça sobre si. Talvez a ignorância esteja da mesma forma longe do quadro de elementos acidentais da miséria e da segregação. Talvez seja também uma espécie de crime.

Caberá sempre àqueles que tem ligação ao direito fazer deste um instrumento cada vez mais justo e humano. Obviamente, entendido ser o crime uma questão bem mais social do que jurídica, a punição é bem menos importante do que a igualdade social. A ausência deste pensamento faz com que a academia seja uma formadora de operadores padrão da lei, que a colocam cegamente ao caso concreto sem qualquer juízo decente de valor.

No entanto, observando Nietzche ao analisar a relação dialética no concernente ao confronto, pode-se fazer tênue relação para compreender a corrupção daqueles que, por um instante, ao menos, se sentiram incumbidos a fazer do direito um instrumento de transformação social. De determinada vista, é compreensível, no entanto, aos que mergulham às atrocidades para curá-las ou saná-las, sugere-se extremo cuidado, afinal "quem combate monstruosidades deve cuidar para que não se torne um monstro. E se olhar longamente para um abismo, o abismo também olha para dentro de vocêt ${ }^{14,}$.

Eduardo Galeano, escritor e jornalista uruguaio escreve que a leis são como as serpentes, pois só mordem os descalços ${ }^{15}$. Em integralidade, Galeano tem a razão. Assim, de forma a não ser mais um estudo omisso, não é o objetivo do presente enganar com fantasias ou mentiras, por exemplo, que surgirão em fruto de uma reforma democrática dentro do próprio sistema capitalista. Não existe um único remédio, são soluções universais, portanto, não são exclusivas aos problemas brasileiros, haja vista ser a

\footnotetext{
${ }^{13}$ KAFKA, Franz. O processo. $10^{\mathrm{a}}$ reimpressão. Tradução e Posfácio de Modesto Carone. Companhia de Bolso, 2005.

${ }^{14}$ NIETZCHE, Friedrich. Para além do bem e do mal: prelúdio a uma filosofia do futuro. $1^{\text {a }}$ edição. Martin Claret, 2002.

15 "La justicia es como las serpientes, sólo muerde a los descalzos".
} 
questão criminológica em conjunção à judiciária, uma problemática global, não há que se falar em determinismo para tais aspectos.

Primeiramente, o tratamento "peçonhento" que a lei confere aos crimes - mesmo aos menores - como um dos grandes algozes da criminalidade deve ser extirpado. O sistema carcerário, não só brasileiro, mas em dimensões mundiais, é fator que em nada colabora com a situação. As grades são verdadeiras agravantes para aqueles que cometem crimes, pois aqueles que lá entram, não sairão de lá minimamente reeducados em suas condutas.

Ora, a pena como instrumento de ressocialização e reeducação deveria, pelo menos, agir como tal. No entanto, o que se percebe é que a pena de fato, tornou-se mero mecanismo estatal de segregação, assim como toda a ideia de sistema carcerário se tornou meio de fazer valer a insulação. Não obstante, existem hoje, presídios que se encontram privatizados, transformando a pena e a prisão em um negócio, em inevitável mercantilização das punições onde a empresa, impossibilitada de desgarrar-se de suas atribuições funcionais, vê no suplício um meio de lucro, na pena a propaganda e no preso, o marketing. Além disso, é tão enaltecida esta ideia de desestatização da pena que, faz parecer que a direção é criar um branding ante o sistema de punitivo, quase como criar o desejo do produto crime para atrair público ao mercado.

É intencional aos objetivos maiores que regem o planejamento que a lei continue criando inimigos determinados em uma escala cada vez mais assustadora. Assim se percebe, além de pela lex, pelas punições. Afinal, o que são as cadeias e penitenciárias se não formadores de criminosos profissionais, de cabeça íntegra ao crime.

Alimentando a ideia de crime, criminoso e punição, se consegue manter a ideia de que a lei é para todos e funciona para todos. Mais ainda, se consegue a legitimação destes ideais por aqueles que mais sofrem em suas garras.

O mecanismo legal necessita urgentemente cessar suas atenções e atendimentos ao senso comum. Aqueles que criam as leis, o fazem para si, o fazem para atender à ignorância do eleitorado. O que acontece é que, os que necessitam da lei não são os mesmos que a financiam, portanto, não são aqueles que a protegem.

Os códigos, principalmente o penal, quer queira ou não, funcionam como máfia, como milícia institucionalizada: aqueles que podem, pa- 
gam por sua própria proteção, aqueles que não podem, fatalmente irão perecer nas mãos da violência estatal, que não tem moderação. Pode-se discutir que tenha em teoria, mas na prática é tomada como certa e ideal por quase todos.

Não existe uma medida única que fará, para sempre, extinguir a ideia de inimigo que esfacela o país e o mundo a todo instante. São inúmeras essas tomadas de decisões, e são extremamente urgentes, é inadiável a extirpação do sistema punitivo atual, o fim do senso comum no âmbito político, a criação de meios reais, verdadeiros de ressocialização, tratamento e reeducação.

Caso contrário, as serpentes continuarão rastejando e picando aqueles que, de fato, precisam de sua proteção. Ademais, as serpentes somente sobreviverão se continuarem protegidas por aqueles que são suas verdadeiras vítimas.

Segundo conta a mitologia grega, Sísifo era um pastor de ovelhas, sendo também filho do deus dos ventos, Éolo. Em razão de ardis praticados em vida, após sua morte natural, recebeu condenação, juntamente com Prometeu, Títio, Tântalo e Ixíon. Seu suplício consistia em, por toda a eternidade, rolar uma enorme pedra de mármore até o topo de uma montanha. Assim sendo, quando estava quase a completar o trabalho, a pedra rolava - por meio de uma força descomunal - montanha abaixo até o ponto de partida $^{16}$.

Na óptica de muitos a ideia que o mito de Sísifo passa é usada para retratar trabalhos infrutíferos, inúteis, que não apresentem resultados.

Desta forma age a criminologia mundial, em especial a brasileira. Se pune cegamente, vendo na punição meio de reduzir a criminalidade. Alguns ainda a veem como fim. No entanto, os cegos não se apercebem do que a punição como ponto central da situação pós cometimento do crime pode causar.

Não se pode fechar os olhos e pensar que o pesar da situação repousa unicamente sobre a criminologia, mas sim também sobre todo o Estado e sobre toda a formação social. Assim se diz, pois, o sistema penal como forma de aplicação de norma e, por consequência, modeladora de qualquer conceito de justo, é o reflexo mais violento que a força estatal

${ }^{16}$ CAMUS, Albert. O mito de Sísifo: ensaio sobre o absurdo. Exilado dos Livros. 
exerce sobre as camadas baixas da sociedade. Este reflexo violento e animalesco exercido tão limpidamente é a pura atividade repressiva institucional, não por direito, mas por fato.

Antes de qualquer conclusão precipitada, é importante sempre frisar que jamais, nos moldes da sociedade capitalista, o Estado será a força ou o impulso que levará ao caminho ou ao próprio objetivo. Desta forma se conclui haja vista como ente próprio e proveniente das forças burguesas - dos moldes costumeiros, da formação de classes e da própria disposição enquanto instituição -, o Estado florescerá viciado, de modo que para que a pedra pare de rolar montanha abaixo, é necessário que o povo faça por si valer o que lhe é de direito. Enquanto perdurar a nébula coletiva sobre a falsa noção democrática, a plebe será esmagada, dia após dia, paulatinamente, e convencida de que é totalmente livre pois pode reclamar sozinha.

A luta incessante para punir cada vez mais, eficiente e gravemente crimes é uma luta que reflete Sísifo, tendo como protagonistas deste show de horrores a população massiva, os entes do legislativo, do executivo e principalmente do judiciário. Diz-se principalmente, pois destes se deve presumir o mínimo de senso humano, porém, é predominantemente destes que se obtêm jurisprudências e entendimentos cada vez mais repressivos.

A realidade brasileira reflete muito bem a pedra que é carregada, pois assim é feito de maneira desgastante e infrutífera. Enquanto seres humanos definham e se desfazem dentro de suas próprias casas, vidas e celas, os poderes tergiversam, colocando sua condição de humano no mesmo patamar de suas, ou seja, imagina-se que o pobre que reside nas favelas e nas periferias, está igualmente incluído nos padrões morais do que aqueles que criam os dispositivos legais.

O resultado é simples e mais do que óbvio: a pedra rola montanha abaixo. É esquecido que, o ser humano em sua condição racional, porém animal, está sujeito a instintos que visam garantir sua sobrevivência. Desta feita, aqueles que jamais foram postos a prova, são os primeiros a julgar e opinar sobre a "queda" daquele que é diariamente colocado face a face com a fome, a miséria e a falta de humanidade que o sistema propriamente produz.

Assim sendo, o rolar da pedra simboliza a queda do ser humano, e consequentemente a queda da sociedade. Cada vez que um crime é cometido, toda a sociedade entra em ruína. A esfera do indivíduo infrator é punida, mas pouco se percebe que está se punindo, em inúmeros casos, a mera condição humana que está inerente a todos, sem exceção nenhuma. 
Aqui, passa-se a observar que existe uma criminalização do instinto, como se constantemente o homem comum buscasse se desvencilhar de suas raízes. Não se pode condenar tal almejo, no entanto, este objetivo poderá ser inicialmente cogitado, quando todos estiverem em pleno estado de conservação mental e física, senão, todos estão fadados a inevitavelmente, cair nas redes do instinto.

O rolar da pedra, enquanto a condenação de Sísifo perdurar, será infinito. A criminalidade, enquanto os olhos não notarem que o crime está inserido no contexto social - e minimamente moral - do indivíduo, será infinita, ela só irá crescer, porque por mais que exista um simbolismo penal por parte daqueles que enganam, a realidade mostrará a face, mais cedo ou mais tarde. A queda deste sistema insustentável é, fatalmente, inevitável. Até lá, o Brasil - e o mundo todo - será sempre o que o Professor Darcy Ribeiro chama de "moinho de gastar gente ${ }^{17 "}$.

\section{CONSIDERAÇÕES SOBRE A INABSTRAÇÃO DENTRO DO SISTEMA ACADÊMICO JURÍDICO}

Agora, é importante que se entenda, mais uma vez, e de uma vez por todas, que não existe um único remédio para a situação que se apresenta, não há no plano sumário, uma solução. O que vai curar esta imensa chaga na sociedade são pequenas manifestações, atitudes e movimentos ilhados. Explica-se: Usando o que se pode depreender do magistério de Michel de Certeau ${ }^{18}$, um grande sistema pode suportar uma grande avalanche, principalmente em países como o Brasil. Portanto, o que se poderia fazer para derrubar uma sistemática que domina todas as instituições, desde a lei, aos meios de comunicação?

Certeau leciona que, podendo suportar uma grande onda, este grande mecanismo não pode suportar pequenas explosões que se unem internamente. No entanto, como seriam feitos tais atos? Há de se convir que são conceitos difíceis e que demandam certa explicação.

${ }^{17}$ RIBEIRO, Darcy. O povo brasileiro: a formação e o sentido do Brasil. São Paulo. Companhia das Letras, 2006.

${ }^{18}$ CERTEAU, Michel de. A invenção do cotidiano - 1. Artes de Fazer. Editora Vozes. 15ª Edição, 2008. 
A tática que é apresentada se assemelha às técnicas utilizadas pelas guerrilhas. Desta forma, os caminhos para que os objetivos sejam cumpridos são únicos em sua natureza. Assim, são criadas forças paralelas para que, em conjunto da sociedade que percebe os clamores daqueles que necessitam, mantenham os seres humanos respeitados como tal. Em outras palavras, resistências se formam de maneira não institucional com o intuito de enfraquecerem as garras daqueles que os oprimem.

É necessário que se entenda de uma vez por todas, que o sistema capitalista, formado como é e estruturado como sempre foi é o verdadeiro criador de inimigos. As instituições são a mera instrumentalização do que se chama de superestruturas.

Não se pode, a partir do momento que se toma a consciência da óptica que a sociedade se opera, teorizar reformas, amplidão de garantias, ou então observar a lei como um fator psicológico, moral e de conduta independente dos demais aspectos do corpo social. Todo este complexo funciona de modo a atirar migalhas àqueles "dignos", assim, não se pode cair em ingenuidade a ponto de imaginar que um grupo de especialistas criarão dentro do terreno segregacionista, uma descentralização ou um cerco indireto que permitirá a todo ser humano ser tratado como tal. Em outras palavras, o direito jamais será a força responsável a promover a revolução em todo o quadro humano, não podendo ser analisado de forma apartada das demais instituições, pois é um fruto destas, da forma mais violenta. Além disso, acrescenta-se que, enquanto o direito inserir-se à sociedade capitalista da forma como faz, será sempre um forte ente criador e fomentador de toda esta guerra.

Não se trata de preservar determinadas garantias e outras não, trata-se de perceber que toda a criação destas, é feita em detrimento de outras, e não só, pois a institucionalização das garantes é o maior dos pretextos para sua violação, senão a única razão de institucionalizá-las. A fantasia que o estudo do direito propõe é perigosa e somente pode ser combatida com a efetiva destruição de todas as relações de poder, sejam elas hierárquicas, legais ou contratuais.

Ademais, o conceito jurídico de garantias e sua aplicabilidade prática surge como não absoluto, e não só por isso, a necessidade de previsão legal para o "poder/fazer" da lei atinge um patamar venturoso ante o Estado de Direito, porque se as garantias existem, tais são, como toda a instituição jurídica, uma fantasia aos desavisados, principalmente pelo fato de que se erguem como se fossem situações violadas preteritamente - e em 
verdade ainda serão -. Os direitos que são conferidos aos prisioneiros sejam eles de fato criminosos ou não - é maleável, existe para que seja descumprido ou relativizado a depender de quem seja colocado no banco dos réus, para que o plebeu, ao olhar para os olhos do juiz e de seu acusador, se coloque em seu devido lugar.

A ingenuidade daqueles que veem o direito como mantenedor de garantias, a lei como o estrato da reserva da moralidade de um território não poderá mais ser preservada. $\mathrm{O}$ que não se pode mais ter em plano é que uma busca por garantias plenas no plano legal resolverá minimamente o problema.

$\mathrm{Na}$ verdade, enquanto perdurarem as relações de exploração entre os indivíduos nas quais o direito surge como elemento inerente, não haverá que se falar, em hipótese alguma, em direito de fato, senão institucionalizado, tendo em vista que, para que seja este pleno, é indispensável que todos, sem distinção alguma, sejam postos em igualdade perante a sociedade, perante a lei e perante seus iguais:

Todo direito é um golpe. É a forma do engendramento da exploração do capital e da correspondente dominação de seres humanos sobre seres humanos. Tal golpismo jurídico se faz mediante instituições estatais, sustentando-se numa ideologia jurídica que é espelho da própria ideologia capitalista. Sendo o direito sempre golpe, a legalidade é uma moldura para a reprodução do capital e para a miríade de opressões que constituem a sociabilidade. Todo o direito e toda a política se fazem a partir de graus variados de composição entre regra e exceção. (...). O direito é forma social capitalista. Sua materialidade se funda nas relações entre portadores de mercadorias que se equivalem juridicamente na troca. A forma jurídica é constituinte da sociabilidade capitalista. O mesmo quanto à forma política estatal, terceira necessária em face dos agentes da exploração capitalista. O Estado, mesmo quando governado por agentes e classes nãoburguesas, é capitalista pela forma. Direito e Estado se arraigam nas relações sociais capitalistas, estando atravessados pelas vicissitudes e contradições de tal sociabilidade da mercadoria. Legalidade e política 
estão submetidas à dinâmica acumulação, nacional e internacional. ${ }^{19}$

Na verdade, o próprio conceito de liberdade como meio e fim de Lipovetsky, e a formulação de "aldeia global" de McLuhan, tão sinuosos ao sistema que predomina mundialmente, será útil como caminho de transformação social. Desta vez, a "migalha" de liberdade atirada ao povo foi por boa parte bem digerida.

A verdade é que são movimentos de cunho popular que se mostram minúsculos se comparados ao imenso poderio que os persegue. Outra verdade quase absoluta é que, enquanto qualquer movimento de ascensão de qualquer classe oprimida for minoria - tendo em vista que a classe oprimida é, de fato, a esmagadora maioria - não haverá que se falar em transmutação social, revolução, reforma ou qualquer outro mecanismo de equiparação entre pessoas. Afinal, como exaustivamente mostrado até agora, isto não é acidental, é parte integrante de toda a sistemática perfeita e perversa.

$\mathrm{Na}$ verdade, qual o real efeito de citar teorizações, velocidades, conceitos e devaneios sobre o direito objetivo e subjetivo, sobre o poder/dever da lei e sobre a sociedade? De fato, não há qualquer acréscimo senão puramente abstração rasa e claramente sem uso. Conhecer profundamente algumas férteis ideias podem ser poderosos meios de orientação, mas não salvarão aqueles que precisam do amparo legal e ao mesmo tempo, não salvarão os necessitados do próprio amparo legal.

Explorar as vias que segregam como turismo intelectual tal qual se faz com a pobreza e a miséria não poderia ser mais do que puro egocentrismo, além de ser de extrema inutilidade. Aliás, teorizar é de extrema importância para destruir paradigmas e criar novos conceitos, no entanto, aqueles que o fazem pelo mero exercitar não são mais do que instrumentos e mantenedores das condições inimizantes, principalmente por serem parte fundante, que abandonam o intelecto de prócere, mas com o agir de um verdadeiro anti-herói.

Todo o conceito de autoridade já pressupõe toda uma hierarquia social, assim como toda uma estrutura de poder, a qual, por sua vez, resulta

${ }^{19}$ MASCARO, Alysson Leandro, em: "Todo direito é um golpe". 
em acondicionar pessoas em classes opressoras e oprimidas ${ }^{20}$. Atribuir superioridade entre indivíduos é legitimar o descontrole da igualdade, e assim se diz, pois ante a fragilidade de nações perante impérios globais, qualquer colocação de pessoas sobre pessoas é pura ilusão, é dar longa manus aos magnatas. Na verdade, o que ocorre é uma infiltração do poder punitivo na sociedade civil, como um Big Brother ${ }^{21}$ real e onipresente, que possui o corpo daqueles que adentram às instituições e a alma daqueles que sadicamente com elas simpatizam sem saber que são, também, parte do alvo principal.

A vida deste instrumento de repressão é descartável aos imperadores, são facilmente substituíveis, afinal, são a instrumentalização do poder, como uma longa manus desprovida de poder. O que é preciso compreender é que a repressão infiltrada e generalizada persiste em razão da contaminação de pessoas como entes massacrados, porém defensores de seus verdadeiros agressores:

A IDEIA de POLÍCIA é como a hidra em que crescem cem novas cabeças para cada uma que é decepada - e todas essa cabeças são policiais vivos. Cortar fora as cabeças não nos ajuda em nada, apenas aumenta o poder da besta até que ela nos engula. /// Primeiro assassine a IDEIA - exploda o monumento dentro de nós - e então, talvez... o equilíbrio do poder se inverterá. Quando o último tira em nosso cérebro for assassinado pelo último desejo não satisfeito - talvez até mesmo a paisagem ao nosso redor comece a mudar... ${ }^{22}$

É verdade que o inimigo hoje é reconhecido institucionalmente por lei, legitimado e criado pela mídia e assegurado desta forma e condição pelo aparelho policial repressivo, que usa de membros da classe inimiga para fazê-los sentir dotados de privilégios como seus algozes são, mantendo-as, no entanto, somente no campo da abstração e iludindo aqueles

${ }^{20}$ ENGELS, Friedrich e MARX, Karl. O manifesto do partido comunista. Tradução de Marcos Aurélio Nogueira e Leandro Konder. $2^{a}$ ed. Petrópolis, RJ. Editora Vozes. p. 40.

${ }^{21}$ Referência ao "Grande Irmão" da obra "1984", de George Orwell.

${ }^{22}$ BEY, Hakim. CAOS: terrorismo poético e outros crimes exemplares. Conrad Editora do Brasil. 2007. Comunicado \#4, p. 27. 
que acreditam prestar um nobre serviço a favor do corpo social. $\mathrm{O}$ direito, na égide de sua vertente penal é o meio mais eficiente para a plena gestão da miséria no sistema capitalista.

É da mesma forma verdade que aquele reconhecido como inimigo é agente que não produz, ou seja, é o vadio, o "vagabundo". O que torna determinado indivíduo como respeitável perante a óptica social é sua produção de capital de exploração, ou seja, o quanto suporta a exploração laboral ou, do outro lado, será sua acumulação do próprio capital explorado. Em outros termos, aquele que não é produtivo será taxado e rotulado e, fatalmente, será um hostis, e tais relações persistem de forma vívida a partir da legitimação jurídica:

Dessa maneira, o vínculo social entre as pessoas no processo de produção, reificado nos produtos do trabalho e que assume a forma de princípio elementar, requer para sua realização uma relação particular entre as pessoas enquanto indivíduos que dispõem de produtos, como sujeitos 'cuja vontade reside nessas coisas'. (...). Por isso, ao mesmo tempo que um produto de trabalho adquire propriedade de mercadoria e se torna portador de um valor, o homem adquire um valor de sujeito de direito e se torna portador de direitos. Sujeito do direito é o ente cuja vontade é decisiva ${ }^{23}$.

A atitude dos agradados perversos que dão origem a estas atrocidades é de certa forma, compreensível, pois se orgulham de sua "honestidade" e julgam louvável aplicar a sua realidade à daqueles aos quais a lei é imposta, se orgulham de uma integridade que - nos mesmos moldes às dos inimigos - nunca foi posta à prova, nunca sentiram as dores que a fome e a miséria podem causar, porém são os primeiros a berrar contra o esfaimado.

Via de regra, a sociologia aponta que as camadas de criação de um indivíduo enquanto cidadão devem agir desta forma, ou seja, a família como célula mater faz o primeiro trabalho de aprimoramento do ser humano como ser civilizado. Desta maneira, no último estágio de "anomalia"

${ }^{23}$ PACHUKANIS, Evguiéni B. Teoria geral do direito e marxismo. $1^{\text {a }}$ ed. São Paulo. Boitempo Editorial, 2017. p. 120. 
no qual uma pessoa pode estender-se - e também chegado o final da linha que a sociedade consegue suportar - o Estado agirá como ente educador. Em outras palavras, o civilizado que não se age como tal se torna bárbaro, e após esta repentina transformação, será encarcerado para que se "reeduque" ou se reestruture aos padrões burgueses de ser e estar.

A razão pela qual não se entende adequada tampouco oportuna esta linha é a de ser a ideia de um discurso punitivo e fomentador da indústria do encarceramento, que vai inevitavelmente criar, novamente, inimigos certos e determinados, além de obviamente cair às ideias de punição como meio e fim de soluções à criminalidade.

Da mesma forma se pode dizer sobre os dizeres de Jakobs, ao diagnosticar a questão do direito penal do inimigo. Jakobs leciona que não se encontram mais condições para curar a chaga do "inimigo". O que se pode vislumbrar seria, como conceitua o Professor, uma "proposta estática de contenção", o que, segundo Zaffaroni, não tem absolutamente nada de inovadora, haja vista que praticamente toda a teoria penal, assim como o direito penal, sempre reservou um certo espaço para o tratamento do inimigo $^{24}$, ou, como Jakobs chama, o "destinatário de tratamento diferenciado".

A simbologia jurídica emergencial no que tange à prática penal, tem atuado de forma exemplar no concernente a acalmar as labaredas dos garantistas-punitivistas. A criminalização de movimentos e grupos sociais aplaudida pelo conservadorismo torpe é a outra face da moeda dos missionários das reformas legais que se regozijam ao ver também o inimigo ideológico se tornar prisioneiro.

Os agrupamentos não percebem que, a cada vez que o ente estatal político torna ilegal o modo de agir de outrem, está apenas satisfazendo as vontades para que se torne cada vez mais legitimado e instituído. Com isso, não está sendo permitido que a segregação possua voz ou lugar, o que se propaga é que a criminalização primária ou secundária é mera criação de conceitos burgueses convenientes, nada mais é do que o Estado agindo de forma a legitimar a luta sectária e também prosperar a queda dos próprios inimigos.

\footnotetext{
${ }^{24}$ ZAFFARONI, Eugenio Raúl. O inimigo do direito penal. Editora Revan. Rio de Janeiro, 2007. p. 190.
} 
Além de serem ideais que ainda proclamam uma doutrina punitiva, são remédios de curto prazo, que, ao longo do tempo, impreterivelmente criarão novos inimigos padronizados e/ou pré-estabelecidos, como já fazem no presente e sempre fizeram no passado.

Tal problemática não encontra no direito, em seus operadores e acadêmicos a real atenção que demanda, da maneira mais infeliz que se possa imaginar -seja pela mercantilização da educação e, consequentemente, do ensino jurídico ou seja pela cultura pouco sensitiva à real situação do direito como ontologia - simplesmente depositando-se em fatores sociais demasiada responsabilidade, e mais ainda, a culpa por este holocausto que se presencia. Novamente, não de forma acidental.

Muitos ainda se dizem apegados demais a realidade para que a ideia seja posta realmente em andamento, porém, ao andar da sociedade omitir-se não deve ser opção. Outrossim, aqueles que de qualquer forma conseguem olhar sobre o muro da segregação têm obrigação moral de buscar sempre e incessantemente meios de desconstrução do sistema predominante, acrescendo Ferrer, principalmente quando sujeitos a governanças de punho pesado, como uma força insurgente que foi criada e subvertida:

Se comprenderá que un movimiento de ideas tan radical haya nacido casi extinto. Su tareas eran las de un Hércules; sus enemigos, antiguos e inmensos como pirámides; y sus fuerzas, limitadas (...) Fueron sus cabezas de tormenta. Los primeros en anunciar y promover algunas libertades que hoy se disfrutan en partes del mundo (...) De no haber existido anarquistas nuestra imaginación política sería más escuálida, y más miserable aún. ${ }^{25}$

Não se pode, porém, imaginar ou projetar que tais revoluções se concretizem com rapidez, afinal, devem ser eficazes. Desta forma, não se pode planejar que tudo se transforme em uma noite ou com uma reforma ou uma emenda legal, pois a destruição de todos os conceitos legais e morais, inclusive todo o aparelho de senso comum dependerá de inúmeros fatores contextuais, fatores estes que, presentemente, não permitem de forma alguma sonhar com estas conquistas.

${ }^{25}$ FERRER, Christian. Cabezas de tormenta: ensayos sobre lo ingovernable. Buenos Aires: Utopia Libertaria, 2006. p. 11-12. 
Há sim a permissão e o dever de sonhar e buscar que isso se materialize, ser, sob os dizeres de Warat, poeta que floresce em si a rebeldia, ou seja, destruidor de tudo e de si mesmo, que, transcendendo tudo que é imposto, apresenta o que o mesmo chama de uma "proposta destrutiva", um modo de desaprender o aprendido de forma imposta ${ }^{26}$.

Aqueles que atingem grau minimamente superior de instrução pessoal - ou seja, aqueles que de qualquer forma se aproximam aos pés dos opressores - detêm meios e deveres para com a sociedade. Assim sendo, abandonar a busca ou mudá-la de plano é atentar contra os seus semelhantes e contra o próprio estado de direito. É, mais ainda, passar a fazer parte do capacho dos tiranos ${ }^{27}$.

Sonhar é necessário, lutar incansavelmente ainda mais, buscar a verdade é indispensável, no entanto, a ação de fato, move a história e o futuro:

El sueño no es el contrario de la realidad. Es un aspecto real de la vida humana, así como la acción; uno y otra, lejos de excluirse, se complementan (...) contiene los fermentos de la revuelta más violenta por ser los más violentamente humanos. Se comprende que la voluntad de oscurantismo de los maîtres à penser se haya manifestado siempre por un desprecio total en relación con el sueño. Su inteligencia se limitó a tolerar (y tal vez a favorecer) la difusión de las 'Claves de los Sueños', obras desnaturalizadas, de carácter puramente supersticioso, fantasioso o idiota. Pero los pueblos que el odioso buen sentido europeo se obstina en

\footnotetext{
${ }^{26}$ WARAT, Luís Alberto. O ofício do mediador. Florianópolis. Habitus, 2001. p. 279.

${ }^{27}$ BOÉTIE, Étienne de La. Discurso da servidão voluntária. LGE Editora. $1^{\text {a }}$ edição, 2009. Nesta obra, Boétie chama de "tiranos" os poderosos, os próceres, criadores, os governantes, visto o verdadeiro esteio de servidão que criam perante a população que, ante sua inércia e ignorância, está fadada a ser escravizada. Verbis: "Assim são os tiranos: quanto mais eles roubam, saqueiam, exigem, quanto mais arruínam e destroem, quanto mais se lhes der e mais serviços se lhes prestarem, mais eles se fortalecem e se robustecem até aniquilarem e destruírem tudo. Se nada se lhes der, se não se lhe obedecer, eles, sem ser preciso luta ou combate, acabarão por ficar nus, pobres e sem nada; da mesma forma que a raiz, sem umidade e alimento, se torna ramo seco e morto".
} 
denominar 'primitivos' (primitivo porque nunca conocieron los secretos de la bomba atómica, o simplemente de la hipocresía diplomática) conceden al sueño un lugar de primer orden. (...) Se sabe ahora que no existe sueño gratuito, que por el simples hecho de soñar el hombre cambia su destino, aun cuando ese cambio sea imperceptible. (...) Cuando, una noche, todos los explotados sueñen que es preciso terminar y cómo terminar con el sistema tiránico que los gobierna, entonces, tal vez, la aurora surgirá en todo el mundo, sobre las barricadas ${ }^{28}$.

É o direito, como todo, é uma serpente, é a punição como meio ou fim, uma pedra na exausta jornada de Sísifo, enquanto um incessantemente é demasiadamente eficiente em seu serviço, por obviedade àquilo que se propõe, o outro é totalmente ineficiente, é insensato e muito brutal. A população vive no interior de um viveiro de cobras, enquanto ainda sofre com o rolar da pedra, com a penalidade imposta a Sísifo. É, assim, feita como plebe propriamente dita.

Quase todo o meio jurídico - principalmente uma parcela perigosa, falaciosamente dita como acadêmica -, transformado e afetado pela mercantilização do curso superior, são tomados por ideais tratados como pontos comuns e puramente hierárquicos de forma que, de forma impreterível - mesmo que inconscientemente - legitimam a inimização de indivíduos pelo direito. Se tornam parte do dardo que acerta o alvo.

Já é chegada a hora de ser a explosão interna, as movimentações ilhadas. A necessidade de um suposto crescimento pessoal que se impõe à nova geração possui este propósito, obviamente intrínseco. A questão mercadológica que cargos altos, salários colossais, estabilidades e vitaliciedades oferecem são uma das grandes forças motrizes que impedem a racionalização do curso superior, em especial o de direito, que faz seus discentes reféns, como o próprio vestibular já o fez anteriormente.

Dentre tudo isso, com efeito reverso ao que se propôs como democratização do ensino universitário, a mercantilização do aprendizado finda por acomodar jovens a padrões, que viajam desde da personalidade e, inevitavelmente passam para a profissionalização. A ausência do senso

${ }^{28}$ COELHO, Plínio Augusto. Surrealismo y Anarquismo: "proclamas anarquistas” en Le Libertaire. Buenos Aires, colección Utopía Libertaria, 2005. 
crítico, quando toma conta do sistema estudantil, interno ao curso de direito, vai ser o grande legitimador do deslocamento social, principalmente daquele que o abismo social educacional representa.

A derradeira premissa que se deve ter sempre em mente é que, o sistema segregacionista é, de fato, duradouro, senão infinito. É, de fato, sedutor ao senso comum, é realmente confortável aos pensamentos. No entanto é frágil, e assim é, porque o único elo que o perfaz é o apoio - mesmo que silencioso - das massas, é a força braçal dos próprios servos, seja do trabalho das maiorias, seja pela conivência do meio jurídico, o que permite constatar que, a segregação, assim como todo o instrumento que a acondiciona é um castelo de areia próximo à maré alta, pois este se sustenta por suas próprias forças, porém, cedo ou tarde irá desmoronar e se dissolver na própria areia que um dia o escorou de forma tão firme.

Não importa o tamanho e o número de construções feitas, todas perecerão ante a força gigantesca da maré, mesmo que existam mil castelos sobre a costa. Para tanto, somente é necessário e inadiável que as ondas do mar passem a agir como tal.

\section{REFERÊNCIAS BIBLIOGRÁFICAS}

AMBOS, Kai. Derecho penal del inimigo. Tradução de Carlos GómezJara Diéz y Miguel Lamadrid. Colombia: Universidad Externado de Colombia, 2007.

BEY, Hakim. CAOS: terrorismo poético e outros crimes exemplares. Conrad Editora do Brasil. 2007.

BINDING, Karl; HOCHE, Alfred. La licencia para la aniquilación de la vida sin valor de vida. Tradução de B. Sergiós. Buenos Aires: Ediar, 2009.

BODIN, Jean. De la demonomamie des sorciers. De l'inquisition des sorciers. Livro IV, Capítulo 5, "De la peine qui méritent les sorciers", 215-217, Paris, chez Jacques du Pues, Libraire Iuré, 1587.

BOÉTIE, Étienne de La. Discurso da servidão voluntária. LGE Editora. $1^{a}$ edição, 2009.

CAMUS, Albert. O mito de Sísifo: ensaio sobre o absurdo. Exilado dos Livros.

CERTEAU, Michel de. A invenção do cotidiano - 1. Artes de Fazer. Editora Vozes. 15 Edição, 2008. 
COELHO, Plínio Augusto. Surrealismo y Anarquismo: "proclamas anarquistas" en Le Libertaire. Buenos Aires, colección Utopía Libertaria, 2005.

ENGELS, Friedrich e MARX, Karl. O manifesto do partido comunista. Tradução de Marcos Aurélio Nogueira e Leandro Konder. $2^{\mathrm{a}}$ ed. Petrópolis, RJ. Editora Vozes.

FERRER, Christian. Cabezas de tormenta: ensayos sobre lo ingovernable. Buenos Aires: Utopia Libertaria, 2006.

FOUCAULT, Michel. Em defesa da sociedade. São Paulo. Martins Fontes, 2005.

Informativo Rede Justiça Criminal - Quais são os números da justiça criminal no Brasil?

KAFKA, Franz. O processo. $10^{\mathrm{a}}$ reimpressão. Tradução e Posfácio de Modesto Carone. Companhia de Bolso, 2005.

Levantamento Nacional De Informações Penitenciárias Infopen - 2014.

LOMBROSO, Cesare. O homem delinquente. Tradução de Sebastião José Roque. Ícone, 2007.

MASCARO, Alysson Leandro, em: "Todo direito é um golpe".

NIETZCHE, Friedrich. Para além do bem e do mal: prelúdio a uma filosofia do futuro. $1^{a}$ edição. Martin Claret, 2002.

PACHUKANIS, Evguiéni B. Teoria geral do direito e marxismo. $1^{\text {a }}$ ed. São Paulo. Boitempo Editorial, 2017.

PIRES, Guilherme Moreira e CORDEIRO, Patrícia. Abolicionismos e cultura libertária: inflexões e reflexões sobre estado, democracia, linguagem, delito, ideologia e poder. Editora Empório do Direito. 2017.

PRITTWITZ, Cornelius. O direito penal entre o direito penal do risco e o direito penal do inimigo: tendências atuais entre direito penal e política criminal. Revista Brasileira de Ciências Criminais, n. 47. São Paulo: Revista dos Tribunais, mar. - abr. 2004.

RIBEIRO, Darcy. O povo brasileiro: a formação e o sentido do Brasil. São Paulo. Companhia das Letras, 2006.

STEINBECK, John. As vinhas da ira. Tradução de Herbert Caro e Ernesto Vinhaes. 10a edição. Editora Record, 2012.

WARAT, Luís Alberto. O ofício do mediador. Florianópolis. Habitus, 2001.

ZAFFARONI, Eugenio Raúl. O inimigo do direito penal. Editora Revan. Rio de Janeiro, 2007. 